\title{
INCORPORATION OF ALKALINE-EARTH METALS Ca, Mg, Ba and Sr IN MCM-41 FOR APPLICATION AS CO2 ADSORVENTS IN THE PRE- SALES NATURAL GAS CURRENTS
}

\section{INCORPORAÇÃO DE METAIS ALCALINOS TERROSOS Ca, Mg, Ba E Sr EM MCM-41 PARA APLICAÇÃO COMO ADSORVENTES DE CO 2 NAS CORRENTES DE GÁS NATURAL DO PRÉ- SAL}

\author{
T. R. S. RIBEIRO ${ }^{1, *}$, D. C. M. SILVA ${ }^{1}$, T. P. M. COSTA $^{1}$ and A. O. S. SILVA ${ }^{1}$
}

${ }^{1}$ Federal University of Alagoas, Department of Chemical Engineering, Maceió, Alagoas, Brasil

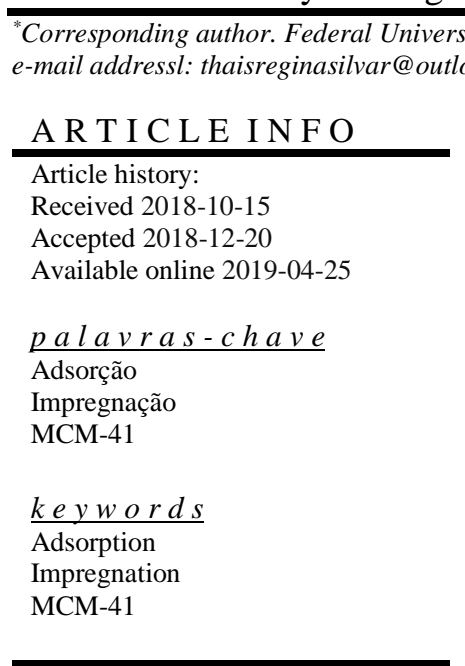

\begin{abstract}
A B S T R A C T
The new oil fields discovered in the Pre-Salt Province have large oil reserves, but the technological challenges for their economic exploitation are enormous. One of the problems with these reservoirs is that the associated gas has high concentrations of carbon dioxide, which must be removed and disposed of properly. In this way it is necessary to develop technologies for the separation of $\mathrm{CO}_{2}$ from natural gas streams, but there is a complication for these new technologies; the fact that they must be able to treat currents with relatively high concentrations of carbon dioxide. In the present project, the alkaline-earth cations $\mathrm{Ca}, \mathrm{Mg}$, $\mathrm{Ba}$ and $\mathrm{Sr}$ in the molecular sieve MCM-41 will be impregnated for adsorption in natural gas streams, as this modification will provide the formation of acid sites favoring the adsorption reaction.

R E S U M O

Os novos campos de petróleo descobertos na Província do Pré-Sal possuem grandes reservas de petróleo, porém os desafios tecnológicos para a sua exploração de forma econômica são enormes. Um dos problemas com esses reservatórios são que o gás associado possui altas concentrações de dióxido de carbono, que deve ser removido e disposto apropriadamente. Dessa forma é necessário se desenvolver tecnologias para a separação de $\mathrm{CO}_{2}$ de correntes de gás natural, mas há um complicador para estas novas tecnologias; o fato de que elas devem ser capazes de tratar correntes com concentrações relativamente altas de dióxido de carbono. No presente projeto será feita a impregnação dos cátions alcalinos terrosos $\mathrm{Ca}, \mathrm{Mg}, \mathrm{Ba}$ e $\mathrm{Sr}$ na peneira molecular MCM-41 para adsorção nas correntes de gás natural, pois esta modificação irá proporcionar a formação de sítios ácidos favorecendo a reação de adsorção.
\end{abstract}




\section{INTRODUCTION}

Excessive emissions of greenhouse gases in recent decades have led to global warming, a problem that causes rising ocean levels, increased occurrence of storms, hurricanes, and other weather phenomena related to the warming of the atmosphere. Gases such as carbon dioxide $\left(\mathrm{CO}_{2}\right)$, methane $\left(\mathrm{CH}_{4}\right)$, nitrous oxide $\left(\mathrm{N}_{2} \mathrm{O}\right)$ and water vapor $\left(\mathrm{H}_{2} \mathrm{O}\right)$ are responsible for maintaining the earth's temperature by retaining radiation in the infrared length emitted by the earth's surface, cause the planet to overheat.

The need to mitigate the impacts caused to the environment by the emission of carbon dioxide, together with the possibility of using it in the industrial and power generation sectors, has driven the search for new ways of capturing and storing this gas. In this sense, in addition to the traditional techniques for reducing $\mathrm{CO}_{2}$ levels in the atmosphere, such as reducing energy consumption and increasing equipment efficiency; the sequestration processes of carbon appear as an important alternative (Orr Jr, 2004).

In the case of release into the atmosphere from methane separation, the sequestered carbon dioxide is reinjected into the geological formation from which the oil is being extracted. This procedure has already been carried out in some wells in the world and recently began to be implanted in Brazil in pre-salt fields in a definitive way, no longer experimental, while at the same time dealing with environmental impact is also an alternative that increases productivity of the well, therefore, the pressure of the injected $\mathrm{CO}_{2}$ helps increase the oil recovery factor of mature wells, thereby increasing the pressure inside the well. The development of technologies for the separation and capture of $\mathrm{CO}_{2}$ has been considered a priority in the field of carbon sequestration, mainly because the cost of capture is around $75 \%$ of the total cost of geological or oceanic sequestration, and the other $25 \%$ are with transport and injection (Strazisar et al., 2000).

The removal of $\mathrm{CO}_{2}$ in large-scale industrial processes, such as exhaust stream in coal plants, is commonly performed in amine-based absorption columns although the problems associated with corrosion and the high process cost, especially in regeneration, are exhaustively as discussed in the literature (Wang et al., 2011; Zhao et al., 2012).

Adsorption is considered a competitive method against amine washing technology (Amine Scrubbing). In this area, the advances were significant mainly with the development of new adsorbent materials and new strategies in the separation processes (Sayari et al., 2011; Samanta et al., 2012).

The mesoporous silicas such as MCM-41, MCM-48 and SBA-15 are in evidence due to their possible applications as adsorbents or catalytic supports for gas adsorption, phase separation, catalysis, preparation of nanostructured materials among others (Coasne et al., 2006).

The induction of a specific catalytic activity by increasing the number of basic sites can be achieved by incorporating a variety of metals into the mesostructure by direct synthesis, by impregnation or by ion exchange (Eswaramoorthi et al., 2004).

The incorporation of the alkaline earth metals $\mathrm{Ca}, \mathrm{Mg}$, $\mathrm{Ba}$ and $\mathrm{Sr}$, through impregnation in the molecular sieve MCM-
41, will provide the appearance of basic sites favoring the adsorption reaction.

\section{METHODOLOGY}

\subsection{Synthesis of MCM-41}

For synthesis of MCM-41 a gel of the following composition was used CTMABr: 2.62 NaOH: 8.17 TEOS: 2433 $\mathrm{H}_{2} \mathrm{O}$. The reaction mixture was prepared as follows: sodium hydroxide- $\mathrm{NaOH}(76 \% \mathrm{w} / \mathrm{w}$, Merck) was dissolved in all the water required for the synthesis, then cetyltrimethylammonium bromide-CTMABr (98\%, Sigma- Aldrich) was inserted into the solution where it was left under mechanical stirring $(800 \mathrm{rpm})$ at a temperature of $80{ }^{\circ} \mathrm{C}$ for 30 minutes. TetraethoxysilaneTEOS (98\%, Sigma-Aldrich) is added (dropwise) the reaction mixture remaining for a further 2 hours under the same conditions as above.

After this step the solid resulting from the synthesis process was recovered by vacuum filtration, washed with distilled water to neutral $\mathrm{pH}$ and dried in a muffle oven at $70{ }^{\circ} \mathrm{C}$ for two hours.

\subsection{Calcination of Samples}

The removal of the organic residues from the samples of MCM-41 was done by calcination (MCM-41-C) (Bastos, 2004).

The calcination method employed in this study was the following: in a muffle with time and temperature programming, the samples obtained were heated under static conditions at 550 ${ }^{\circ} \mathrm{C}$ for 5 hours under air, with a heating rate of $2{ }^{\circ} \mathrm{C} / \mathrm{min}$.

\subsection{Incorporation of Metals}

The method used for the preparation of supported catalysts was the impregnation based on the work of Quintella 2009. The salts used in the impregnation were as follows:

- Strontium chloride (99\%, Merck);

- Barium chloride (99\%, Merck);

- Calcium chloride (99\%, Merck);

- Magnesium sulphate (99\%, Merck).

The amount of salt added to the solution was about $16 \%$ by mass of the amount of MCM-41-C. The salt containing the metal ion was dissolved in $100 \mathrm{ml}$ of distilled water. Then the solution containing the salt was added to a vessel containing MCM-41-C synthesized, where it remained for 1 hour under mechanical stirring until complete homogenization. The solution was then dried at $120{ }^{\circ} \mathrm{C}$ in a muffle oven.

\subsection{Characterization of Samples}

X-ray diffraction (XRD): The samples were characterized by X-ray diffraction (XRD) using a Shimadzu diffractometer, model XRD-6000, with $\mathrm{CuK} \alpha(\lambda=0.1542 \mathrm{~nm})$, $\mathrm{Ni}$ filter, $40 \mathrm{kV}$ and current of $30 \mathrm{~mA}$. The data acquisition was performed in the range of $2 \theta$ between 1 and $10^{\circ}$, with scan speed of $2^{\circ} / \mathrm{min}$ and step of $0,02^{\circ}$.

Programmed Temperature Desorption (PTD): The measurement procedure takes place in several steps. Initially $300 \mathrm{mg}$ of MCM-41 is placed in a reactor and subjected to a degassing treatment in order to eliminate the substances adsorbed physically to the basic centers. The degassing occurs at a flow rate of $30 \mathrm{ml} / \mathrm{min}$ of helium and a heating rate of 10 
${ }^{\circ} \mathrm{C}$ until reaching the temperature of $500{ }^{\circ} \mathrm{C}$, remaining at that temperature for 1 hour. After degasification, the sample is cooled to room temperature where it is subjected to a $\mathrm{CO}_{2}$ stream $(30 \mathrm{ml} / \mathrm{min})$ for 30 minutes. Then the catalyst is subjected to a helium flow $(30 \mathrm{ml} / \mathrm{min})$ for 30 minutes in order to eliminate the $\mathrm{CO}_{2}$ adsorbed on the surface so that only the $\mathrm{CO}_{2}$ adsorbed chemically remains in the basic centers of MCM41. Finally, the programmed thermal desorption is carried out by subjecting the sample to a heating rate $\left(10^{\circ} \mathrm{C} / \mathrm{min}\right)$ under helium flow $(30 \mathrm{ml} / \mathrm{min})$ from ambient temperature to $800{ }^{\circ} \mathrm{C}$, remaining at that temperature for 30 minutes.

The $\mathrm{CO}_{2}$ that is desorbed at different temperatures is drawn by the helium stream and recorded thereby obtaining the TPD-CO $\mathrm{CO}_{2}$ curve.



Figure 1 - X-ray diffraction of calcined MCM-41 and MCM-41 samples.

\section{RESULTS}

\subsection{Characterization of Samples by X-ray Diffraction}

From the procedures described in the methodology the samples of pure MCM-41 and with impregnation of $\mathrm{Ca}, \mathrm{Mg}, \mathrm{Ba}$ and $\mathrm{Sr}$ salts were prepared. Figure 1 shows the effect of calcination on MCM-41.

After the calcination, it was observed a decrease in the intensity of the peaks characteristic of MCM-41. This decrease in the intensity of the peaks is probably related to the removal of the organic matter present inside the pores (Marler et al., 1996).

From the procedures described in the methodology the
MCM-41 samples were prepared with incorporation of the $\mathrm{Ca}$, $\mathrm{Mg}, \mathrm{Ba}$ and $\mathrm{Sr}$ salts. The X-ray diffractograms of the samples are shown in Figure 2.

When it comes to MCM-41 type materials, the concept of crystallinity can not be used, as in zeolites, because their walls are amorphous silica. The absence of peaks at higher angles indicates that the material is not crystalline, however, it is known that there is an orderly hexagonal network, where one pore is surrounded by other six, generating the characteristic reflections of MCM-41.

MCM-41 samples impregnated with $\mathrm{Ca}, \mathrm{Mg}, \mathrm{Ba}$ and $\mathrm{Sr}$ showed typical X-ray diffraction patterns of MCM-41 mesoporous materials.

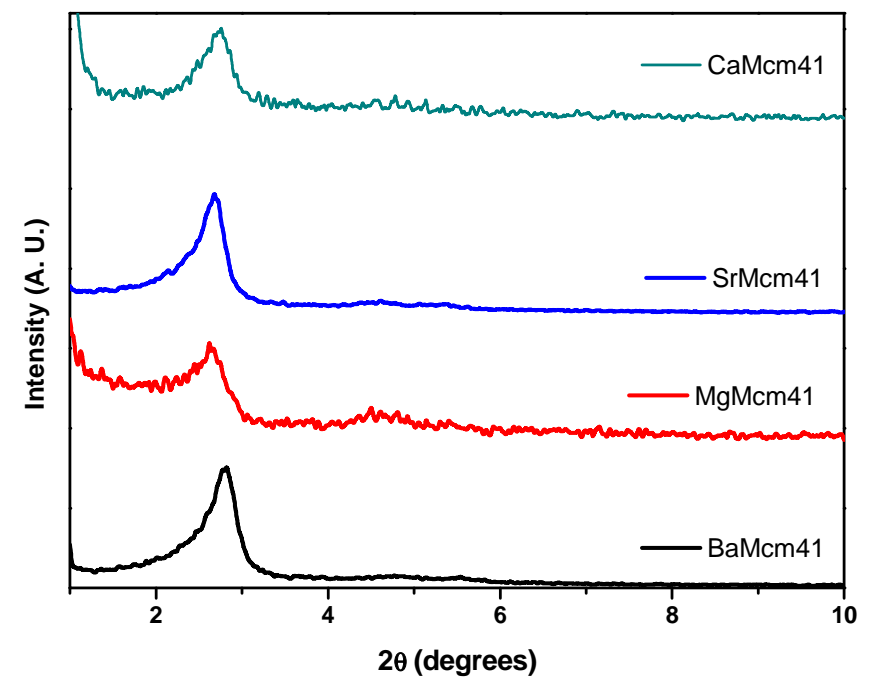

Figure 2 - X-ray diffraction of CaMCM-41, MgMCM-41, BaMCM-41 and SrMCM-41 samples. 


\subsection{Measurements of $\mathrm{CO}_{2}$ Adsorption Capacity}

The technique was performed with the objective of quantifying the basicity of the best synthesized samples. Previous studies have shown that $\mathrm{CO}_{2}$ can be irreversibly adsorbed onto $\mathrm{OH}^{-}$groups (basic sites) in the pores of X-MCM41 producing $\mathrm{CO}_{3}{ }^{2-}$ and $\mathrm{H}_{2} \mathrm{O}$ molecules (Cheng, 1998). However, mesoporous silica / alumina molecular sieves are more known by their acidic properties and their applications in acid-catalyzed reactions (Chaudhari, 2002; Ko, 2001).

The effect of the addition of $\mathrm{Ca}, \mathrm{Mg}, \mathrm{Ba}$ and $\mathrm{Sr}$ alkaline earth cations on the basic properties of MCM-41 was investigated using the TPD- $\mathrm{CO}_{2}$ technique. The TPD profile seen in Figure 3 shows several peaks that correlate with $\mathrm{CO}_{2}$ desorption from different basic surface sites of varying intensities. When analyzing the results of the TPD, it can be verified that all the impregnated samples show desorption peaks between $50{ }^{\circ} \mathrm{C}-200{ }^{\circ} \mathrm{C}$ from $\mathrm{CO}_{2}$ bound to weakly basic sites. The desorption peaks found between $450{ }^{\circ} \mathrm{C}-650{ }^{\circ} \mathrm{C}$ are from the exit of $\mathrm{CO}_{2}$ bound to strong basic sites. The BaMCM-41 sample has a higher peak indicating greater desorption of $\mathrm{CO}_{2}$. These desorption profiles coincide with those found by several researchers using the same alkaline cations, where they verified that the strength of the basic sites increases in the order $\mathrm{BaO}$ > $\mathrm{SrO}>\mathrm{CaO}>\mathrm{MgO}$ (Cadigan et al, 2012).

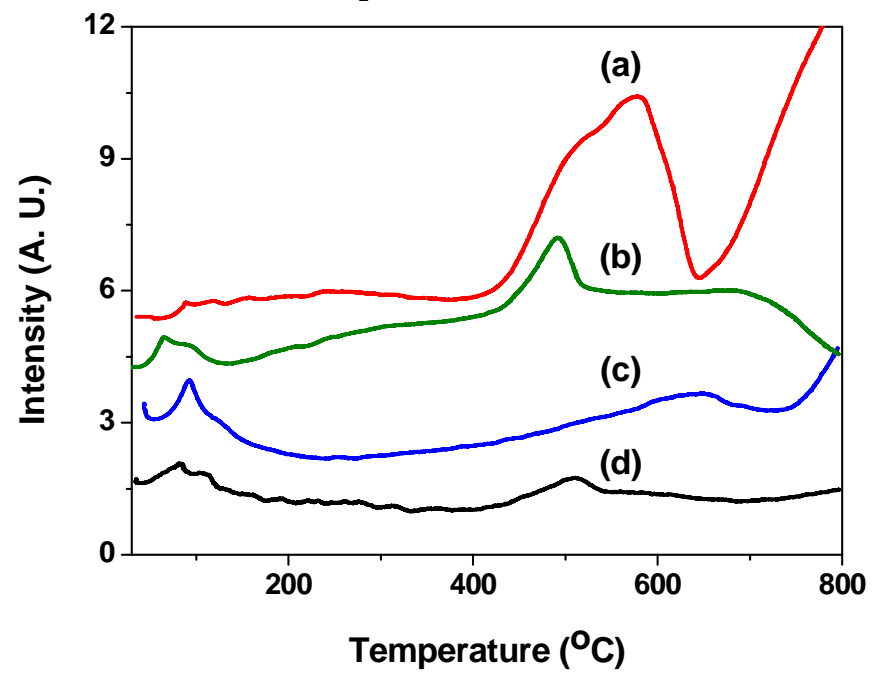

Figure 3 - TPD-CO2 of impregnated MCM-41 samples, where: (a) BaMCM-41, (b) SrMCM-41, (c) MgMCM-41, and (d)

CaMCM-41.

\section{CONCLUSIONS}

From the obtained results it is seen that through the characterization techniques, it is possible to understand the organization and the form of the material and to analyze the samples, in order to conclude that the impregnation of the alkaline earth metals $\mathrm{Ca}, \mathrm{Mg}, \mathrm{Ba}$ and $\mathrm{Sr}$ was successfully performed, the BaMCM-41 sample had a higher $\mathrm{CO}_{2}$ adsorption capacity compared to the other impregnated samples.

\section{R E F E R E N C E S}

COASNE, B.; GALARNEAU, A.; RENZO, F.; PELLENQ, J. M. Gas adsorption in mesoporous micele-templated sílicas: MCM-41, MCM-48, and SBA-15. Langmuir, Marseille, France, v. 22, p. 11097-11105, 2006.

CHENG, Z. H., YASUKAWA, A., KANDORI, K., ISHIKAWA, T. FTIR Study of Adsorption of CO2 on Nonstoichiometric Calcium Hydroxyapatite. Langmuir, Osaka, Japan, v. 14, p. 6681-6686, 1998.
CHAUDHARI, K., BAL, R., CHANDWADKAR, A. J., SIVASANKER, S. Beckmann rearrange-ment of cyclohexanone oxime over mesoporous Si-MCM-41 and Al-MCM-41 molecular sieves. Journal of Molecular Catalysis A: Chemical, Maharashtra, India, v. 177, p. 247-253, 2002.

ESWARAMOORTHI, I.; SUNDARAMURTHY, V.; LINGAPPAN, N. Hydroisomerisation of C6-C7 nalkanes Pt loaded zirconium containing Al-MCM-41 molecular sieves. Microporous and Mesoporous Materials, Chennai, India, v.71, p.109-115, 2004.

MARLER, B.; OBERHAGEMANN, U.; VOLTMANN, S.; GIES, H. Influence of the sorbate type on the XRD peak intensities of loaded MCM-41. Microporous materials, Bochum, Germany, v.6, p.375-383, 1996.

ORR JR, F. M. Storage of Carbon Dioxide in Geologic Formations. Journal of Petroleum Technology, California, United States, v. 56, p. 90-97. 2004.

QUINTELLA, S.A. Síntese, caracterização e propriedades catalíticas da peneira molecular nanoestruturada 
modificada com latânio. 2009. 88f. Tese (Doutorado em Engenharia Química) - Universidade Federal do Rio Grande do Norte, Natal, RN, 2009.

SAYARI, A. Periodic mesoporous materials: synthesis, characterization and potencial applications. Studies in Surface Science Catalysis, Quebec, Canadá, v. 102, p. 1-46, 1996.

SAMANTA, A.; ZHAO, A.; SHIMIZU, G. K. H.;SARKAR, P.; GUPTA, R. Post-combustion CO2 capture using solid sorbents: A review. Ind. \& Eng.Chem. Res., Alberta, Canada, v.51, p. 1438-1463, 2012.

STRAZISAR, BRIAN R.; ANDERSON. RICHARD R., WHITE. CURT M. Degradation of monoethanolamine used in carbon dioxide capture from flue gas of a coalfired electric power generating station. National Energy Technology Laboratory clean air Technology Division, Pittsburgh, Pennsylvania, v. 47, pp 15236, 2000.
WANG, X.; MA, X.; SCHWARTZ, V.; CLARK. J. C.; OVERBURY, S. H.; ZHAO, S.; XU, X.; SONG, C. A solid molecular basket sorbent for $\mathrm{CO} 2$ capture from gas streams with low $\mathrm{CO} 2$ concentration under ambient conditions. Physical Chemistry Chemical Physics, Pennsylvania, United States, v. 14, p. 1485, 2011.

ZHAO, B.; SU, Y.; TAO, W.; LI, L.; PENG, Y. Postcombustion $\mathrm{CO} 2$ capture by aqueous ammonia: A stateof-the-art review. International Journal of Greenhouse Gas Control, Shanghai, China, v. 9, p. 355371, 2012.

CADIGAN. C. A; CORPUZ A. R.; LIN F.; CASKEY C. M.; FINCH K. B. H; RICHARDS X. W; RICHARDS R. M. Nanoscale (111) faceted rock-salt metal oxides in catalysis. Catal. Sci. Technol., Colorado, United States, v. 3, p. 900-911, 2013. 